\title{
Goat ovarian follicles express different levels of mRNA for inhibin-BA subunit and activin-A stimulates secondary follicle growth in vitro
}

\author{
Folículos ovarianos caprinos expressam diferentes níveis de RNAm para subunidade BA da inibina e \\ ativina-A promove o crescimento de folículos secundários in vitro
}

\begin{abstract}
Cintia Camurça Fernandes Leitão ${ }^{\mathrm{I}}$ José Jackson Nascimento Costa $^{\mathrm{I}}$ Márcia Viviane Alves Saraiva ${ }^{\mathrm{II}}$

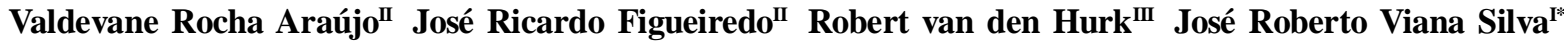

\begin{abstract}
This study investigated the levels of messenger ribonucleic acids ( $m R N A$ ) for inhibin- $\beta A$ subunit in goat primordial, primary and secondary follicles, as well as in cumulus-oocyte complexes (COCs) and mural granulosa / theca cells of antral follicles. The effects of activin-A (100ng $\left.\mathrm{mL}^{-1}\right)$ and/ or follicle stimulating hormone (FSH, 50ng $\mathrm{mL}^{-1}$ ) on growth and expression of mRNA for activin-A and FSH receptor (FSH$R)$ in secondary follicles cultured for six days were evaluated. The data showed that the expression of inhibin- $\beta A$ is lower in secondary follicles than in primary follicles and is higher in large antral follicles than in small antral follicles. After culture, activin-A and/or FSH promoted growth of secondary follicles, while FSH increased the levels of mRNA for inhibin- $\beta A$, and activin-A increased the levels of FSH-R mRNA. In conclusion, $m R N A$ for inhibin- $\beta A$ is expressed at different levels in pre-antral and antral follicles and activin-A acts as a stimulator of the FSH-R expression in goat follicles. On its turn, the expression of inhibin- $\beta A$ is stimulated by FSH, which together with activin-A promotes secondary follicle growth in-vitro.
\end{abstract}

Key words: pre-antral follicles, caprine, culture, oocyte, antrum formation, FSH-R.

\section{RESUMO}

Este estudo investigou os níveis de ácidos ribonucleicos ( $R N A m$ ) para a subunidade $\beta A$ da inibina em folículos primordiais, primários e secundários caprinos, bem como em complexos cumulus-oócitos (CCOs) e células da granulosa mural/teca de folículos antrais. Além disso, avaliaram-se os efeitos da ativina-A (100ng $\mathrm{mL}^{-1}$ ) elou hormônio folículo estimulante (FSH, $50 \mathrm{ng}^{\mathrm{mL}} \mathrm{L}^{-1}$ ) sobre o crescimento e a expressão do RNAm para inibina- $\beta A$ e receptores de FSH (FSH-R) em folículos secundários cultivados por seis dias. Os dados mostraram que a expressão de inibina$\beta A$ é menor em folículos secundários do que em folículos primários e é maior em grandes folículos antrais que nos pequenos folículos antrais. Após o cultivo, ativina-A elou FSH promoveram o crescimento de folículos secundários. Enquanto o FSH aumentou os níveis de RNAm para inibina- $\beta A$, a ativinaA aumentou os níveis de RNAm para FSH-R. Em conclusão, a inibina- $\beta A$ é expressa em diferentes níveis em folículos préantrais e antrais $e$ a ativina-A atua como um estimulador da expressão de FSH-R em folículos caprinos. Por sua vez, a expressão de inibina- $\beta A$ é estimulada pelo FSH, que, juntamente com ativina, promove o crescimento de folículos secundários in vitro.

Palavras-chave: folículos pré-antrais, caprinos, cultivo, oócito, formação de antro, FSH-R.

\section{INTRODUCTION}

Folliculogenesis involves both the development of pre-antral follicles, which is regulated by local factors, and the growth of antral follicles up to a large preovulatory follicle, that is highly dependent of gonadotrophins. It is well known that during follicle growth and maturation in-vivo, the vast majority of oocytes enclosed in pre-antral follicles became atretic (MARKSTRÖM et al., 2002). To avoid this huge loss of oocytes, some studies (ROMERO \& SMITZ, 2009; MAGALHÃES et al., 2010) have demonstrated that

'Programa de Pós-graduação em Biotecnologia, Universidade Federal do Ceará (UFC), Av. Maurocélio Ponte, 100, 62042-280, Sobral, CE, Brasil. E-mail: jrvsilva@ufc.br. *Autor para correspondência.

"Faculdade de Veterinária, Universidade Estadual do Ceará (UECE), Fortaleza, CE, Brasil.

IIIVeterinary Faculty, Utrecht University, PO Box 80.163, Utrecht, The Netherlands. 
secondary follicles $(\sim 200 \mu \mathrm{m})$ can grow up to antral stages in a long term culture system. In these studies, the effects of various hormones and epidermal growth factor have been evaluated and recently oocyte maturation and in-vitro embryo production have been described for goats (SARAIVA et al., 2010; MAGALHÃES et al., 2011). Despite the success of these studies, the in-vitro maturation of isolated preantral follicles and fertilization of in-vitro matured oocytes still have a very low efficiency, resulting in a small production rate of embryos. Considering that activin-A promotes growth of secondary follicles in other species (ovine: THOMAS et al., 2003, bovine: MCLAUGHLIN et al., 2010), quantification of its levels during follicular development in-vivo, as well as evaluation of its effects on goat secondary follicles invitro is very important for the establishment of an ideal culture medium.

Activin-A is a dimeric glycoprotein composed of two $B$ subunits of inhibin A. In goats, mRNAs for inhibin $B A$ subunit and for activin receptors (ActRIIA, ActRIIB, ActRIA, ActRIB) have been demonstrated in primordial, primary, secondary and antral follicles (SILVA et al., 2004), but the level of mRNA for inhibin $B A$ at different stages of development is still not known. In bovine, the intraovarian effects of activin-A includes proliferation of granulosa cells (MCLAUGHLIN et al., 2010) by potentiating FSH action via up-regulation of FSH receptors (KNIGHT \& GLISTER, 2006). FSH receptors are expressed in goat ovarian follicles at different stages of development, but it is unknown if activin-A up-regulates FSH-R expression during growth and potentiates FSH action in-vitro. When tested on goat follicles, activin-A stimulates growth of primordial and primary follicles and increases the percentage of healthy follicles (SILVA et al., 2006). Moreover, stimulation of development of secondary follicles has been achieved by adding activin-A (MCLAUGHLIN et al., 2010) and/or FSH (WANDJI et al., 1996) to the culture medium. Thus, it is hypothesized that, in goats, activin-A in presence of FSH stimulates both the development of secondary follicles and the expression of inhibin-BA subunit and FSH-R in cultured follicles.

This study evaluated the levels of mRNA for inhibin-ßA subunit in caprine primordial, primary and secondary follicles, and in COCs, mural granulosa and theca of small and large antral follicles. Moreover, we studied the effects of activin-A and FSH on the growth of secondary follicles, and the influence of activin-A and FSH on the levels of mRNA for FSH-R and inhibinBA subunit in 6-days cultured secondary follicles.

\section{MATERIAL AND METHODS}

Messenger RNA quantification for inhibin-ßA subunit in caprine ovarian follicles

To evaluate mRNA expression, ovaries $(n=30)$ of goats (Capra hircus) were collected from a slaughterhouse and rinsed in saline $(0.9 \% \mathrm{NaCl})$ containing $100 \mathrm{IU} \mathrm{ml}^{-1}$ penicillin and $100 \mu \mathrm{g} \mathrm{ml}^{-1}$ streptomycin. Then, 10 ovaries were utilized for isolation of primordial, primary, and secondary follicles as previously described (LUCCI et al., 1999). From a second group of ovaries $(n=20)$, COCs aspirated from small $(1-3 \mathrm{~mm})$ and large $(3-6 \mathrm{~mm})$ antral follicles were recovered. Compact COCs were selected from the follicle content as described by VAN TOL \& BEVERS (1998). Thereafter, groups of 10 COCs were stored at $80^{\circ} \mathrm{C}$ until RNA extraction. To collect mural granulosa / theca cell complexes, small $(\mathrm{n}=10)$ and large $(\mathrm{n}=10)$ antral follicles were isolated from ovaries $(\mathrm{n}=5)$ and dissected free from stromal tissue with forceps as described by VAN TOL \& BEVERS (1998). The follicles were then bisected, where after mural granulosa / theca cell complexes were collected and stored at $-80^{\circ} \mathrm{C}$.

Isolation of total RNA and synthesis of complementary deoxyribonucleic acid (cDNA) were performed as described previously (CELESTINO et al., 2011). Quantification of the mRNA for inhibin- $ß A$ subunit was performed by using real-time quantitative polymerase chain reaction (PCR). PCR reactions were composed of $1 \mu \mathrm{l}$ cDNA as a template in $7.5 \mu 1$ of SYBR Green Master Mix (Applied Biosystems, Foster City, CA), $5.5 \mu l$ of ultra-pure water, and $0.5 \mu \mathrm{M}$ of each primer. The primers were designed to perform amplification of mRNA for inhibin $\beta A$ (sense [s]: atatcggagaaggtggtggatgct; antisense [as]: actgctcacaggcaatccgtatgt), FSH-R (s: aggcaaatgtgttctccaacctgc; as: tggaaggcatcagggtcgatgtat), and housekeeping genes B-Actin (s: accactggcattgtcatggactct; as: tccttgatgtcacggacgatttcc), ubiquitin (s: gaagatggccgcactcttctgat; as: atcctggatcttggccttcacgtt) and $\beta$-tubulin (s: ttcattggcaa cagcacagcca; as: tcgttcatgttgctctcagcct). The thermal cycling profile for the first round of PCR was: initial denaturation and activation of the polymerase for $15 \mathrm{~min}$ at $94^{\circ} \mathrm{C}$, followed by 40 cycles of $15 \mathrm{sec}$ at $94^{\circ} \mathrm{C}, 30 \mathrm{sec}$ at $60^{\circ} \mathrm{C}$, and $45 \mathrm{sec}$ at $72^{\circ} \mathrm{C}$. The final extension was for $10 \mathrm{~min}$ at $72^{\circ} \mathrm{C}$. All reactions were performed in a real time PCR Mastercycler (Eppendorf, Germany). The delta-delta cycle threshold (CT) method was used to transform CT values into normalized relative expression levels, by relating the $\mathrm{CT}$ value of the target gene in a sample to a calibrator sample and to the $\mathrm{CT}$ values of reference genes (LIVAK \& SCHMITTGEN, 2001). 
Effect of activin-A and FSH on growth of caprine secondary follicles and mRNA expression

Ovaries of goats $(n=10)$ were collected, as described previously, and kept at $32^{\circ} \mathrm{C}$. In the laboratory, ovarian cortical slices ( 1 to $2 \mathrm{~mm}$ in diameter) were cut from the ovarian surface, using a surgical blade. The ovarian cortex was subsequently placed in fragmentation medium, consisting of minimum essential medium (MEM) plus HEPES. Secondary follicles of approximately $200 \mu \mathrm{m}$ in diameter were visualized under a stereo microscope (SMZ 645 Nikon, Tokyo, Japan) and manually dissected from strips of ovarian cortex, using 26 gauge (26G) needles. After isolation, follicles were transferred to $100 \mu \mathrm{L}$ drops containing fresh medium under mineral oil to further evaluation of the follicular quality. Follicles with a visible oocyte, surrounded by granulosa cells, an intact basement membrane and no antral cavity were selected for culture.

For in-vitro studies, after their selection, follicles were individually cultured in $100 \mu \mathrm{L}$ drops of culture medium in petri dishes $(60 \times 15 \mathrm{~mm}$, Corning, USA). Control culture medium consisted of $\alpha$-MEM (pH 7.2-7.4), supplemented with $3.0 \mathrm{mg} \mathrm{mL}^{-1}$ bovine serum albumin (BSA), ITS (insulin 10 $\mu \mathrm{g} \mathrm{mL}^{-1}$, transferrin $5.5 \mu \mathrm{g} \mathrm{mL}^{-1}$ and selenium $5 \mathrm{ng} \mathrm{mL}^{-1}$ ), $2 \mathrm{mM}$ glutamine, $2 \mathrm{mM}$ hypoxantine and $50 \mu \mathrm{g} \mathrm{mL}^{-1}$ of ascorbic acid under mineral oil. Incubation was conducted for 6 days at $39^{\circ} \mathrm{C}$ with $5 \% \mathrm{CO}_{2}$. For treatments, control culture medium was supplemented with 50ng $\mathrm{mL}^{-1}$ of FSH $\left(\mathrm{rFSH}^{\circledR}\right.$, Nanocore, Brazil), 100ng $\mathrm{mL}^{-1}$ of activin-A (Sigma, St. Louis, USA), or both. These concentrations of FSH and activin-A were those that promoted the highest growth rates in in-vitro cultured pre-antral follicles in previous studies (SILVA, et al., 2006; MATOS, et al., 2007). For culture, the follicles were randomly chosen and then incubated for 6 days in an incubator, under $5 \% \mathrm{CO}_{2}$ in air and at $39^{\circ} \mathrm{C}$. Every other day, $60 \mu \mathrm{L}$ of the culture media was replaced by fresh medium. The culture was replicated four times, and 30 follicles were used per treatment involving a total of 120 follicles. At the end of a culture, follicular morphology and diameter, as well as the percentage of follicles that had an antrum were assessed. To evaluate the effect of activin-A, FSH and their combination on the expression of the mRNA for FSH-R and inhibin- $\beta A$ subunit in cultured goat follicles, respectively, for each treatment, three groups of eight follicles were collected at the end of the 6-day culture period and then stored at $-80^{\circ} \mathrm{C}$ until extraction of total RNA.

The nonparametric Kruskal-Wallis test was used to compare data of mRNA for inhibin-ßA subunit in uncultured primordial, primary and secondary follicles, and the levels of mRNA for inhibin-BA subunit and FSH-R in cultured follicles. The t-test was used to compare mRNA expression in uncultured small and large antral follicles and follicular diameter before and after culture. Data of follicular growth by the different treatments were transformed to $\log 10$ and compared by the Student-Newman-Keuls test. The chi-square test was used to compare the percentage of follicles that had formed an antrum. Data were considered to be significantly different from others when $\mathrm{P}<0.05$.

\section{RESULTS}

Messenger RNA expression of inhibin-ßA subunit in caprine ovarian follicles

Quantification of mRNA for inhibin-ßA subunit showed a significant reduction of its levels during the transition of primary follicles to the secondary stage $(\mathrm{P}<0.05$, Figure 1). There was no significant difference in levels of mRNA for inhibin-ßA subunit between primordial and primary follicles $(\mathrm{P}>0.05)$. In addition, there was no significant difference between COCs of small and large antral follicles, but mural granulosa cell / theca cell complexes from large antral follicles had higher levels of mRNA for inhibin- $\beta A$ subunit than those from small antral follicles $(\mathrm{P}<0.05$, Figure 1$)$.

In-vitro growth of caprine follicles and expression of inhibin-ßA subunit and FSH-R

Compared to noncultured secondary follicles (day 0), independent of the treatment, a significant increase in follicular diameter was observed after culturing such follicles for six days. Compared to culture in MEM alone, addition of FSH, activin-A or both significantly increased follicular growth $(\mathrm{P}<0.05)$, but no positive interaction between FSH and activin was observed. In addition, no significant effects of treatments were observed in the percentage of antrum formation (55 to $75 \%$ of follicles developed antrum) (Table 1).

Compared to culture of secondary follicles in MEM alone, culture in MEM supplemented with FSH significantly increased the follicular levels of mRNA for inhibin-BA subunit (Figure 2). However, culture of follicles in MEM supplemented with activinA or both activin-A and FSH showed levels of mRNA for inhibin-ßA subunit comparable to those observed in follicles cultured in MEM, but lower that those levels observed in follicles cultured with FSH alone (Figure 2). Addition of activin-A to MEM significantly increased the level of mRNA for FSH-R in cultured follicles, whereas addition of FSH or a mixture of FSH and activin-A had no effect (Figure 2). 


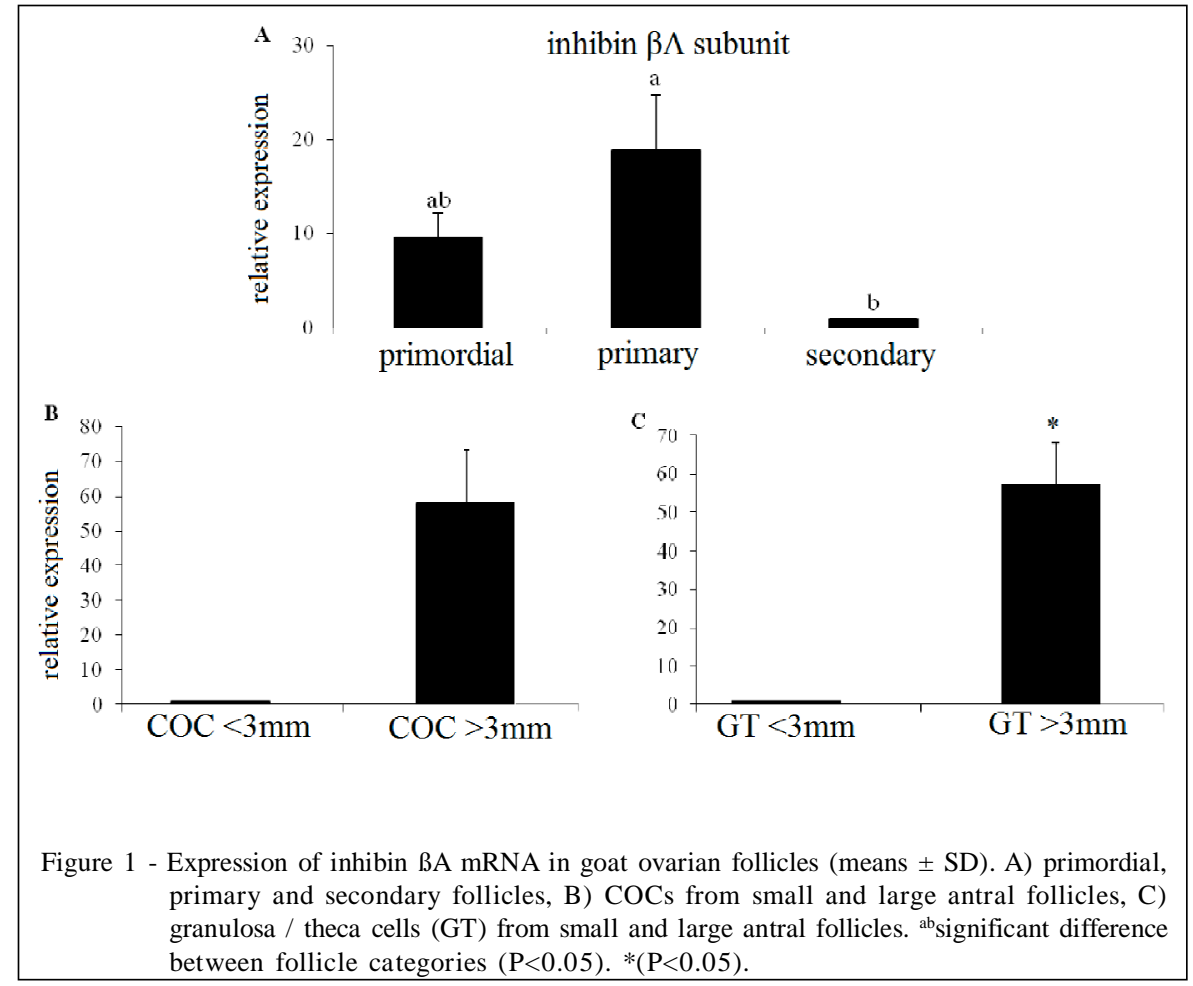

\section{DISCUSSION}

This study is the first that showed a decrease in mRNA for inhibin-BA subunit during the transition of primary follicles to the secondary stage. Probably activin-A coming from neighboring large antral follicles is down-regulating the expression of transcripts for inhibin- $\beta A$ within secondary follicles. To reinforce this hypothesis, our results showed that, in the presence of FSH, exogenous activin-A down-regulates expression of inhibin $B A$ in cultured goat secondary follicles. In addition, ANTENOS et al. (2008) demonstrated that activin-A reduces the levels of inhibin $B A$ and stimulates endogenous production of inhibin $\alpha$ - and $\beta B$-subunit mRNA in gonadotrope cells. Using PCR, inhibin-BA mRNA expression was detected in the oocyte and somatic cells of rat secondary follicles (ZHAO et al. 2001). These authors furthermore demonstrated that activin-A did not only promote the growth of rat secondary follicles, but also antrum formation. A stimulating effect of activin-A on goat primary follicle development in vitro was also

Table 1 - Follicular diameter and antrum formation after culture of secondary follicles in MEM supplemented with FSH, activin-A or both.

\begin{tabular}{lccc}
\hline Treatment & $\begin{array}{c}\text { Day 0 } \\
\text { Diameter }(\mu \mathrm{m}) \pm \text { SEM }\end{array}$ & $\begin{array}{c}\text { Day 6 } \\
\text { Diameter }(\mu \mathrm{m}) \pm \text { SEM }\end{array}$ & $\begin{array}{c}\text { Follicular Growth } \\
(\mu \mathrm{m}) \pm \text { SEM }\end{array}$ \\
\hline MEM & $208.5 \pm 8.0$ & $301.0 \pm 14.8^{*}$ & $\begin{array}{c}\text { Antrum formation } \\
(\%)\end{array}$ \\
MEM + FSH & $233.2 \pm 7.2$ & $363.5 \pm 12.6^{*}$ & $9^{*} \pm 9.6^{\mathrm{a}}$ \\
MEM + activin-A & $201.2 \pm 6.3$ & $355.3 \pm 23.9^{*}$ & $67.8 \%(16 / 29)$ \\
MEM + activin-A + FSH & $194.0 \pm 7.4$ & $332.6 \pm 20.9^{*}$ & $154.2 \pm 20.4^{\mathrm{b}}$ \\
\hline
\end{tabular}

* significant difference compared to day $0(\mathrm{P}<0.05)$.

${ }^{\text {ab }}$ significant difference between treatments $(\mathrm{P}<0.05)$.

\$Follicular growth was calculated by using the diameter of viable follicles at day 6 minus diameter of viable follicles at day 0 . 


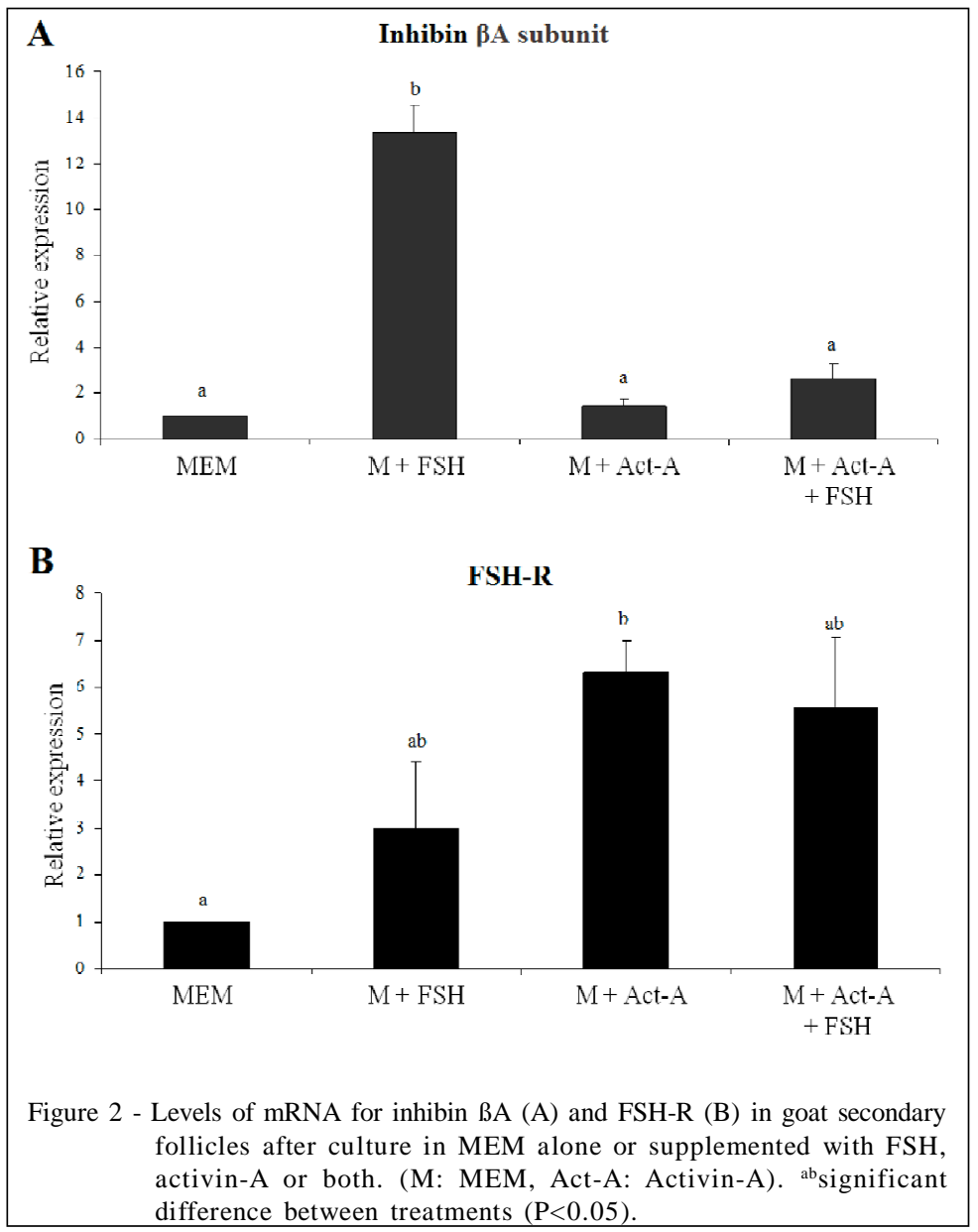

demonstrated by SILVA et al. (2006). Recently, MCLAUGHLIN et al. (2010) showed that activin promoted the follicular integrity and oogenesis in cultured pre-antral bovine follicles.

During growth from small to large antral follicles there was an increase in the levels of mRNA for inhibin- $\mathrm{BA}$ in granulosa and theca cells. It is known that development of antral follicle is marked by increased follicular vascularization and permeability of the blood vessels with consequent increased sensitivity to endocrine factors, like FSH and luteinizing hormone (VAN DEN HURK \& ZHAO, 2005). ANDREONE et al. (2009) demonstrated that FSH stimulates activin-A production in early antral follicles isolated from rat ovaries. Therefore a complex interplay of FSH and paracrine factors during the development of antral follicles may explain changes in expression of inhibin-BA. In goat antral follicles, activin-A protein and mRNA were present in oocytes, cumulus cells, mural granulosa and theca cells (SILVA et al., 2004).
In the current study, activin-A and FSH both increased the growth of goat secondary follicles after a 6-day culture period. FSH is known to stimulate follicular growth and maintain the integrity of granulosa cells in sheep (CECCONI et al., 1999) and cattle (SAHA, et al., 2000). FSH treatment was shown to stimulate oocyte growth in bovine pre-antral follicles in-vitro (ITOH et al., 2002). Culture of ovarian tissue in medium containing FSH resulted in in-vitro growth of caprine pre-antral follicles, while their ultrastructural integrity was maintained (ROSSETTO et al., 2009).

In this study, like FSH, activin-A also improved the growth of cultured secondary follicles. This result is consistent with previous studies in which activin-A stimulated oocyte growth and development of secondary follicles in cows (MCLAUGHLIN et al., 2010) and sheep (THOMAS et al., 2003). Different from ovine follicles (THOMAS et al., 2003), a positive interaction between activin-A and FSH was not observed on goat secondary follicles cultured in vitro. Our results show that treatment of cultured secondary 
follicles with activin-A does increase the follicular level of FSH-R mRNA, which is in accordance with the previously demonstrated activin-induced FSH-R formation in rat granulosa cells (XIAO et al., 1992). When combined with FSH, activin-A similarly also stimulates expression of FSH-R mRNA in granulosa cells from 6-8 $\mathrm{mm}$ hen follicles (JOHNSON et al., 2004). These studies suggest that effects of activin-A on the synthesis of FSH-R appear simultaneous with its role in the amelioration of the sensitivity of follicular cells to this gonadotropin. To explain the absence of a positive interaction between activin-A and FSH on goat cultured follicles, SILVA (2012) demonstrated that activin-A in association with FSH inhibited the expression of proliferating cell nuclear antigen, that is involved in granulosa cell proliferation in bovine preantral follicles. In addition, study by MIZUNUMA et al. (1999) showed that preantral follicles cultured in vitro had a significant increase in size and estrogen secretion in response to FSH, but administration of activin-A blocked the effect of FSH. In our study, FSH had a positive effect on follicular inhibin-BA mRNA levels, while activin-A counteracted the FSH-induced up-regulation. This finding suggests that both FSH and activin-A control the action of activin-A during early follicle growth through modulation of inhibin- $\beta A$ expression.

\section{CONCLUSION}

This study demonstrates a reduction in inhibin- $ß A$ expression during the transition of primary follicles to the secondary stage, and its increase in mural granulosa / theca cell complexes during the development of antral follicles. In cultured secondary follicles, FSH controls the mRNA levels for inhibin$B A$, and activin-A those of FSH-R mRNA. Thus, although activin A and FSH exert a positive effect on the expression of receptors for FSH and inhibin-BA subunit, respectively, there was not a significant increase in the rate of growth of secondary follicles cultured in vitro in the presence of both FSH and activin-A.

\section{REFERENCES}

ANDREONE, L. et al. Regulation of inhibin/activin expression in rat early antral follicles. Molecular and Cellular Endocrinology, v.309, p.48-54, 2009. Available from: <http:// www.sciencedirect.com/science/article/pii/S030372070900269X>. Accessed: Mar. 08, 2011. doi: 10.1016/j.mce. 2009.05.003.

ANTENOS, M. et al. An activin/furin regulatory loop modulates the processing and secretion of inhibin $\alpha$ - and $\beta B$-subunit dimers in pituitary gonadotrope cells. Journal of Biological Chemistry, v.283, p.33059-33068, 2008. Available from: <http://www.jbc.org/content/ 283/48/33059.full>. Accessed: Mar. 12, 2011. doi: 10.1074/jbc.M804190200.

CECCONI, S. et al. In vitro development of sheep preantral follicles. Biology of Reproduction, v.60, p.594-601, 1999. Available from: <http://www.biolreprod.org/ content/60/3/ 594.full.pdf $>$. Accessed: Feb. 15, 2011. doi: 10.1095/ biolreprod60.3.594.

CELESTINO J.J. et al. Steady-state level of epidermal growth factor (EGF) mRNA and effect of EGF on in vitro culture of caprine preantral follicles. Cell Tissue Research, v.344, p.539550, 2011. Available from: <http://www.springerlink.com/ content/ wj1552g54450r017/>. Accessed: Jun. 02, 2011. doi: 10.1007/s00441-011-1162-1

ITOH, T. et al. Growth, antrum formation, and estradiol production of bovine preantral follicles cultured in a serumfree medium. Biology of Reproduction, v.67, p.1099-1105, 2002. Available from: <http://www.biolreprod.org/content/67/ 4/1099.full.pdf+html>. Accessed: Feb. 12, 2012. doi: 10.1095/ biolreprod67.4.1099.

JOHNSON, A.L. et al. Cellular mechanisms and modulation of activin $A$ and transforming growth factor $B$-mediated differentiation in cultured hen granulosa cells. Biology of Reproduction, v.71, p.1844-1851, 2004. Available from: <http://www.biolreprod.org/ content/71/6/1844.full.pdf+html>. Accessed: Feb. 05, 2011. doi: 10.1095/biolreprod. 104.032573.

KNIGHT, P.G.; GLISTER, C. TGF- $\beta$ superfamily members and ovarian follicle development. Reproduction, v.132, p.191206, 2006. Available from: <http://www.reproductiononline.org/content/132/2/191.full.pdf+html>. Accessed: Jan. 26, 2011. doi: 10.1530/rep. 1.01074 .

LIVAK, K.J.; SCHMITTGEN, T.D. Analysis of relative gene expression data using real-time quantitative PCR and the 2- $\Delta \Delta \mathrm{CT}$ method. Methods, v.25, p.402-408, 2001. Available from: <http://www.sciencedirect.com/science/article/pii/ S1046202301912629>. Accessed: Jan. 28, 2011. doi: 10.1006/ meth.2001.1262.

LUCCI, C.M. et al. Effect of the interval of serial sections of ovarian tissue in the tissue chopper on the number of isolated caprine preantral follicles. Animal Reproduction Science, v.56, p.39-49, 1999. Available from: <http://www.sciencedirect.com/ science/ article/pii/S0378432099000317>. Accessed: Apr. 22, 2011. doi: 10.1016/S0378-4320(99)00031-7.

MAGALHÃES, D.M. et al. Effect of the medium replacement interval on the viability, growth and in vitro maturation of isolated caprine and ovine pre-antral follicles. Reproduction in Domestic Animals, v.46, p.134-140, 2010. Available from: <http://onlinelibrary.wiley.com/doi/10.1111/j.14390531.2010.01607.x/pdf >. Accessed: May 05, 2011. doi: $10.1111 / \mathrm{j} .1439-0531.2010 .01607$.

MAGALHÃES, D.M. et al. In vitro production of a caprine embryo from a preantral follicle cultured in media supplemented with growth hormone. Theriogenology, v.75, p.182-188, 2010. Available from: <http://www.sciencedirect.com/science/ article/pii/S0093691X1 0004188>. Accessed: May 05, 2011. doi: $10.1016 /$ j.theriogenology.2010.08.004.

MAO, J. et al. Effects of culture medium, serum type, and various concentrations of follicle-stimulating hormone on 
porcine preantral follicular development and antrum formation in vitro. Biology of Reproduction, v.67, p.1197-1203, 2002. Available from: <http://www.biolreprod.org/content/67/4/ 1197.full.pdf+html>. Accessed: May 05, 2011. doi: 10.1095/ biolreprod 67.4.1197.

MARKSTRÖM, E. et al. Survival factors regulating ovarian apoptosis: dependence on follicle differentiation. Reproduction, v.123, p.23-30, 2002. Available from: <http://www.reproductiononline.org/content/123/1/23.full.pdf+html . Accessed: Apr. 06, 2012. doi: $10.1530 /$ rep.0.1230023.

MATOS, M.H.T. et al. Follicle stimulating hormone and fibroblast growth factor-2 interact and promote goat primordial follicle development in vitro. Reproduction, Fertility and Development, v.19, p.677-684, 2007. Available from: <http:/ /www.publish.csiro.au/?act=view_file\&file_id=RD07021.pdf $>$. Accessed: May 05, 2011. doi: 10.1071/RD07021.

McLAUGHLIN, M. et al. Activin promotes follicular integrity and oogenesis in cultured preantral bovine follicles. Molecular Human Reproduction, v.16, n.9, p.644-653, 2010. Available from: <http:/ /molehr.oxfordjournals.org/content/16/9/644.full.pdf+html>. Accessed: Mar. 22, 2011. doi: 10.1093/molehr/gaq021.

MIZUNUMA, H. et al. Activin from secondary follicles causes small preantral follicles to remain dormant at the resting stage. Endocrinology, v.140, p.37-42, 1999. Available from: <http:/ /endo.endojournals.org/content/140/1/37.full.pdf+html>. Accessed: Jan. 24, 2011. doi: 10.1210/en.140.1.37.

ROMERO, S.; SMITZ, J. Epiregulin can effectively mature isolated COCs, but fails as a substitute for the hCG/EGF stimulus on cultured follicles. Reproduction, v.137, p.997-1005, 2009. Available from: <http://www.reproduction-online.org/content/ early/2009/03/25/REP-08-0523.full.pdf > Accessed: Jan. 27, 2011. doi: 10.1530/REP-08-0523.

ROSSETTO, R. et al. Interaction between ascorbic acid and follicle-stimulating hormone maintains follicular viability after long-term in vitro culture of caprine preantral follicles. Domestic Animal Endocrinology, v.37, p.112-123, 2009. Available from: <http://www.sciencedirect.com/science/journal/ 07397240>. Accessed: Apr. 22, 2011. doi: 10.1016/ j.domaniend. 2009.04.003.

SAHA, S. et al. In vitro culture of bovine preantral follicles. Animal Reproduction Science, v.63, p.27-39, 2000. Available from: <http://www.sciencedirect.com/science/article/ pii/S0378432000001627>. Accessed: Apr. 22, 2011. doi: $10.1016 / \mathrm{S} 0378-4320(00) 00162-7$.

SARAIVA, M.V. et al. Dynamic medium produces caprine embryo from preantral follicles grown in vitro. Reproductive Science, v.17, p.1135-1143, 2010. Available from: <http:// rsx.sagepub.com/content/17/12/1135.full.pdf + html $>$. Accessed: Mar. 12, 2011. doi: 10.1177/1933719110379269.

SILVA, A.W.B. Efeito da ativina-A e do hormônio folículo estimulante (FSH) sobre o desenvolvimento in vitro de folículos pré-antrais bovinos. 2012. 85f. Dissertação (Mestrado em Biotecnologia) - Curso de Pós-graduação em Biotecnologia, Universidade Federal do Ceará, CE.

SILVA, J.R.V. et al. Gene expression and protein localisation for activin-A, follistatin and activin receptors in goat ovaries. Journal of Endocrinology, v.183, p.405-415, 2004. Available from: <http://joe.endocrinology-journals.org/content/183/2/ 405.full.pdf $>$. Accessed: Dec. 12, 2010. doi: 10.1677/ joe.1.05756.

SILVA, J.R.V. et al. The activin-follistatin system and in vitro early follicle development in goats. Journal of Endocrinology, v.189, p.113-125, 2006. Available from: <http://joe.endocrinology-journals.org/content/189/1/ 113.full.pdf $>$. Accessed: Dec. 12, 2010. doi: 10.1677/ joe.1.06487.

THOMAS, F.H. et al. Activin promotes oocyte development in ovine preantral follicles in vitro. Reproductive Biology and Endocrinology, v.1, p.76-83, 2003. Available from: <http: //www.rbej.com/content/1/1/76>. Accessed: Mar. 25, 2011. doi: 10.1186/1477-7827-1-76.

VAN DEN HURK, R.; ZHAO, J. Formation of mammalian oocytes and their growth, differentiation and maturation within ovarian follicles. Theriogenology, v.63, p.1717-1751, 2005. Available from: <http://www.sciencedirect.com/science/article/ pii/S0093691X04002687>. Accessed: Oct. 20, 2010. doi: 10.1016/j.theriogenology.2004.08.005.

VAN TOL, H.T.; BEVERS, M.M. Theca cells and theca cell conditioned medium inhibit the progression of FSH induced meiosis of bovine oocytes surrounded by cumulus cells connected to membrana granulosa. Molecular Reproduction and Development, v.51, p.315-321, 1998. Available from: <http:/ /onlinelibrary.wiley.com>. Accessed: Nov. 05, 2010. doi: 10.1002/(SICI)1098-2795(199811).

WANDJI, S.A. et al. FSH and growth factors affect the growth and endocrine function in vitro of granulosa cells of bovine preantral follicles. Theriogenology, v.45, p.817-832, 1996. Available from: <http://www.sciencedirect.com/science/article/ pii/0093691X96000118>. Accessed: Feb. 25, 2011. doi: 10.1016/0093-691X(96)00011-8.

XIAO, S. et al. Effects of activin and follicle-stimulating hormone (FSH)-suppressing protein/follistatin on FSH receptors and differentiation of cultured rat granulosa cells. Endocrinology, v.131, p.1009-1016, 1992. Available from: <http:// endo.endojournals.org/ content/131/3/1009.full.pdf+html>. Accessed: Feb. 25, 2011. doi: 10.1210/en.131.3.1009.

ZHAO, J. et al. Effect of activin A on in vitro development of rat preantral follicles and localization of activin A and activin receptor II. Biology of Reproduction, v.65, p.967-977, 2001. Available from: <http://www.biolreprod.org/content/65/3/ 967.full.pdf $>$. Accessed: Jan. 21, 2011. doi: 10.1095/ biolreprod65.3.96. 